The Grove. Working Papers on English Studies 27 (2020): 25-40. DOI:

10.17561/grove.v27.a2

\title{
KIM AND KIP IN THE MIRROR OF MIMICRY: A POSTCOLONIAL STUDY
}

\author{
KIM AND KIP EN EL ESPEJO DEL MIMETISMO: UN ESTUDIO \\ POSTCOLONIAL
}

Md Rakibul Islam

Aligarh Muslim University, Murshidabad Centre

mdrakibulislam1989@gmail.com

\author{
Nazia Hasan \\ Aligarh Muslim University \\ naziahasanagha@gmail.com
}

\begin{abstract}
The research paper aims to give an accurate account of how Kirpal Singh/Kip in The English Patient by Michael Ondaatje copies the socio-cultural and linguistic norms of the Europeans (colonizers) unlike Kipling's Kim who emulates the Eastern people (colonized) and their culture. They are examples of going through a long drawn process of growing up, looking into the mirror of mimicry. Kip joins the English army as a grown up, learns the need to show affinity to the new culture by way of imitation, adopting their ways to weave a comfort zone. Being different could be an assaulting fact for both sides, Kip is quick to realize that. But his childish view of looking down upon his native culture is the irony of mimicry. It wipes out the original being to rewrite a new identity. Kip leaves the small community sprouted accidentally in the Italian monastery, showing traces of a stricken conscience. Kim, by the virtue of living in close company of Indians, adopts their habits and manners without any qualm, in a most unconscious manner. He never worries to look or sound his original self which he has not experienced for long. Thus, a kind of reverse mimicry is his fate and character when we look at him as an outsider living as an Indian native. The ambivalence of their characters, presented by both, is an interesting aspect of mimicry. In the paper, we have used the views of postcolonial and cultural literary theorists on mimicry, deliberating upon how with the effect of both the processes, Kip and Kim, consciously or unconsciously, get their national identity peeled off, affixing new hybrid identity.
\end{abstract}

Keywords: ambivalence; colonizers; colonized; hybridity; identity; mimicry. 


\section{Resumen}

El presente artículo de investigación tiene como objetivo proporcionar un relato preciso de cómo Kirpal Singh / Kip en The English Patient de Michael Ondaatje copia las normas socioculturales y lingüísticas de los europeos (colonizadores) a diferencia del Kim de Kipling, que emula a los orientales (colonizados) y su cultura. Ejemplifican el paso por un largo proceso de crecimiento, mirándose en el espejo del mimetismo. Kip se une al ejército inglés como adulto y aprende la necesidad de mostrar su afinidad con la nueva cultura a través de la imitación, adoptando sus formas para sentirse cómodo. Ser diferente podría ser un hecho agresivo para ambas partes: Kip se da cuenta rápidamente de eso. En su visión infantil, que menosprecia su cultura nativa, se plasma la ironía del mimetismo. Borra el ser original para reescribir una nueva identidad. Kip abandona la pequeña comunidad que brotó accidentalmente en el monasterio italiano, mostrando huellas de una conciencia afligida. Al vivir en estrecha compañía con los indios, Kim adopta sus hábitos y modales sin ningún reparo, de la manera más inconsciente. Nunca se preocupa por su ser original, con el que no ha conectado desde hace mucho tiempo. Por lo tanto, su destino es una especie de mimetismo inverso: un forastero que vive como un indio nativo. La ambivalencia de estos personajes es un aspecto interesante del mimetismo. En el artículo hemos utilizado los puntos de vista de los teóricos literarios poscoloniales y culturales sobre el mimetismo para analizar cómo Kip y Kim, consciente o inconscientemente, consiguen desprenderse de su identidad nacional, adoptando una nueva identidad híbrida.

Palabras clave: ambivalencia; colonizadores; colonizado; hibridación; identidad; mimetismo.

\section{Mimicry and Reverse Mimicry}

Mimicry, in general, is defined as an act of imitation, which has its close affinity to other words such as 'parroting', 'copying', and 'emulation' etc., occupies an imperative position in postcolonial study. Mimicry, like sanskritization, works as one of the bludgeons of the social changing process where the colonized people, by force or by choice, imitate the dress, language, and mannerisms of colonizers. Ania Loomba, an Indian literary scholar, has truly explored the colonial influence and its dominancy in her book Colonialism/Postcolonialism (1998): "by the 1930s [the European] colonialism had exercised its sway over 84.6 percent of the land surface of the globe ... Right from its earliest years, it deployed diverse strategies and methods of control and of representation" (Loomba 19). Historically, the Europeans have been enjoying the luxury of being looked upon with awe for a 
steady long time, holding power and superior position while the Eastern people, who were stereotypically thought to be lower class people, looked for upward mobility. The colonized people interacted with the Whites as well as examined their behaviours closely, forming certain aspects of their identities. The Europeans, as vividly explored by Edward Said in his well-received seminal work Orientalism (1978), established a belief that they were more sophisticated, refined, closely controlled, and conversant ones as compared to colonized people who were considered as instinctive, primordial, and ill-bred ones. Accordingly, the people of the 'East', as thought by them, could not rule themselves and it was the White man's burden to rule and civilize them. They took it as their birthright to rule over the 'East' generating an irreconcilable difference: the "Western superiority and Oriental inferiority" (Said 42). "Said argues that representations of the 'Orient' in European literary texts, travelogues and other writings contributed to the creation of a dichotomy between Europe and its 'others" (Loomba 43). The dichotomy, as explored by Loomba, was "central to the creation of European culture as well as to the maintenance and extension of European hegemony over other lands" (Loomba 43). In addition, they started sophisticating their own culture and linguistic norms that had, overtly or covertly, controlled the minds of the Eastern people and led them submerged into the 'cultural well' of the West. The common proverb of the 'crow' and 'swan' might have come out of the same situation - if the crow tries walking like a swan, he ends up forgetting his own way to walk. So, the colonizers slowly started internalizing the culture, linguistic norms, and practices of the colonizers and started feeling at par with them. Consequently, they tried to give up their own culture and values in order to equate themselves to the status of colonizers but failed to completely eradicate their aboriginal identities many a times. Apart from this, its adverse effect also has been observed: when a colonized person mimicked others' ethnic elements, he/she was suspected and judged by his/her own community people as weak in will causing shame and anger, and in addition, his/her own community people used to deride at such person.

Homi K. Bhabha, though the deliberation on the phenomenon of mimicry is not his own creation, defines and explains the term 'mimicry' in an indulging manner in his famous essay "Of Mimicry and Man" taken from The Location of Culture. Mimicry, though he has explored it noticeably, is a mixed derivation from Jacques Lacan's psycho-analytic theory, Jacques Derrida's deconstructive theory, and J. L. Austin's 'performative theory', while exceeding influence of Edward Said and Michel Foucault's 'discursivity' should be noted here. For Bhabha, mimicry works as "a complex strategy of reform, regulation and discipline which appropriates the 'Other' as it visualizes power" (Bhabha 86). The colonizers use mimicry as a strategic tool of the subjugation of the 'Other'/ 'colonized people'. Precisely, "colonial mimicry is the desire for a reformed, recognizable other, as a 
subject of a difference that is almost the same, but not quite" (Bhabha 86). Subsequently, "the discourse of mimicry is constructed around ... ambivalence" (Bhabha 86); the colonized people remain in a state of constant flux or uncertainty. Bhabha brings forth the tension which occurred between the colonizer and colonized, providing slippage on the identity of the colonized that never comes to an end. In one hand, colonial 'mimicry' leads the colonized people to have double identity and on the other hand, they continue in the state of constant fluidity due to cross-cultural encounter, creating an oscillation in their identity. "Bhabha's writings are indeed useful in insisting that neither coloniser nor colonised is independent of the other. Colonial identities - on both sides of the divide - are unstable, agonized and in constant flux. This undercuts both colonialist and nationalist claims to a unified self” (Loomba 149). Jacques Lacan, a well-known psychoanalytic theorist, “... aligns mimicry with the technique of camouflage as 'practiced in human ware'; he lists travesty and intimidation as the other 'major dimensions' in which the mimetic activity is employed" (Myers 66). Furthermore, mimicry acquires an additional dimension in life science: biologists describe it as a self-defense mechanism used by insects to escape any kind of harm. Sometimes, they use it to gain certain advantages also. It makes an interesting study if the humans do it for the same purpose too.

Mimicry sometimes goes beyond such traditional way of imitation and hybridization. It was not only the colonized people or immigrant minorities who always imitated the Whites' dress, culture and their linguistic norms, but also the White colonizers, in disguise or acquiescently, had copied the socio-linguistic norms of colonized people and fantasized them. Thus, in 'reverse mimicry', the 'occupiers' or 'colonizers' imitated and followed the food habit, dressing sense and behaviour of the 'occupied' or 'colonized' people. In spite of such difference, 'reverse mimicry' finds a very close affinity to 'mimicry' and vice-versa as white has with black, and dark has with light. Specifically, the common element which we find in the both processes is 'hybridization' but it takes place in different ways. Consequently, reverse mimicry was considered to be one of the ways to become a 'native', instead of a 'white'. According to Amardeep Singh, an Associate Professor of English at Lehigh University, further elaborates it in his essay, "Mimicry and Hybridity in Plain English": "reverse mimicry, which in the colonial context was often referred to as going native" (2009). To illustrate it further, Singh brings about a "... most famous example of this kind of reverse mimicry ("passing down') might be Richard Francis Burton, who often attempted to disguise himself as Arab or Indian during his time as a colonial administrator" (2009). We can trace the subject of 'passing down' not only in Kipling's Kim but also in Joseph Conrad's Heart of Darkness, depicting Kurtz's possibility of 'going to be native'. 
So far as the present study is concerned, Rudyard Kipling's Kim (1901) and Michael Ondaatje's The English Patient (1992) are set in different time frames. Kim, a colonial text, is a work depicting the British rule in India; whereas Ondaatje's The English Patient, a postcolonial text, traces the slow, heinous process of the colonial erasure, assaulting the entire world in varying degrees. Here, the paper aims to give an accurate and illustrative account on mimicry through the portrayal of a colonizer (represented by Kim) and colonized (represented by Kip). In addition to that, we have specifically tried to deliberate upon how with the effect of both the processes (mimicry and reverse mimicry), they, consciously or otherwise, got their national identity peeled off, and affixing new hybrid identity. The paper further illustrates how the colonial mimicry got reversed; the colonizer internalized the cultural and linguistic norms of the colonized people. Besides Bhabha and Said, the evolutionary views proposed by other postcolonial theorists such as Bill Ashcroft and Frantz Fanon are also applied and correlated during the analysis of the characters (Kim and Kip), while the scholarship of the poststructuralist Jacques Derrida and psychoanalyst Jacques Lacan cannot be neglected here.

\section{Kip and Mimicry}

Michael Ondaatje, a Sri Lankan-born Canadian post-colonial novelist, candidly details 'mimicry' through the portrayal of Kirpal Singh/Kip in his Booker Prize winning fiction The English Patient for he has seen as well as experienced the Western people, their cultural and linguistic norms from very close quarters. Ondaatje has unequivocally revealed the colonial mimicry through the portrayal of Kip, one of the main characters in The English Patient. Kip has fascination for the Western culture and its people has been influenced to a great extent by it not only during his stay at homeland but also at adopted land. Due to such attraction, he reaches in England and works as a sapper there.

The alteration of his name from Kirpal Singh to Kip not only signifies his mere conversion to whiteness but also depicts his "authorized version of Otherness" (Bhabha 88). According to Oxford Advanced Learner's Dictionary, the word 'kip' means "sleep or to sleep" (Hornby 852), especially in a place which is not one's home. England is not Kip's own home rather it is his adopted home, depicting the status of foreignness. 'Kip' also means "the skin of a young animal, especially a calf or lamb" (Robinson and Davidson 749) and "a small thin piece of wood used in the game of two-up for spinning coins" (Robinson and Davidson 749). Here 'lamb' metaphorically may stand for Kip's 'meekness' or 'timidity' while 'spinning coins' covertly may prove the 'de-centric' nature of his identity. Kip's name itself becomes a pun and matter of fun for his colleagues and companions there: "In his first bomb disposal report in England some butter [gets] 
marked his paper, and the officer [has] exclaimed, 'what's this? Kipper grease?' and laughter [surrounds]" (Ondaatje 93). Does he mind it? No. The dictionary meaning of 'kipper' is fish, "a small Salmon" (Robinson and Davidson 749), being cured by salting and smoking in order to make it worth eating. Ironically, same process is followed with Kip; his Indian socio-political identity is cured and recreated as per the requirements of the colonizers like Lord Suffolk, an English captain of his bomb defusing team. Lord Suffolk, along with his team members, prefers to call Kirpal Singh by his nickname Kip. He also accepts the same without much thought. Ironically, it stands for Kip's adaptation of English culture at the cost of abjuring his usual Indian ways. Kip seems willing to wipe out his Indian identity, as if he does not want to exhibit him as an Indian sapper.

As a new comer, Kip is suspicious of everyone in the West. He is unable to feel comfortable anywhere. At the outset, he gazes at Englishmen with 'foreign eye' which indicates his alienation and 'Otherness'. Doubts about his entry in this aspect of army as an Indian engineer are dense and heavy. But somehow, he is also sure of an easy selection if racial discrimination does not play its card. His final selection, despite being a figure of 'Otherness', bridges the East-West gulf, has won the passage. During his interview, when he is peering around a room cautiously, without touching anything there, he is suddenly caught by the eyes of a middle-aged English secretary. She looks at him sternly because his appearance and activities speak out loudly for his state of being a foreigner and a stranger. In the room, his furtive manner of moving towards bookshelves and not daring to touch anything there, putting his nose closely to the books-shelves could ring the alarm bells in any conservative British mind. Suddenly, he again catches the eyes of another woman who is looking at him suspiciously: He feels "... as guilty as if he [has] put the book in his pocket. She [has] probably never seen a turban before" (Ondaatje 200). After all, he is "... a black figure, the background radicalizing the darkness of his skin and his khaki uniform” (Ondaatje 193).

Kip has a half-knowledge of English language as he wrongly mutters the phrase 'very dry' as 'wery dry', but then corrects his pronunciation of 'wery dry' as 'very dry'. Ashcroft, Griffiths, and Tiffin have given an extensive view on such issue of mockery in their book Post-Colonial Studies: Key Concepts in PostColonial Studies:

By adopting the colonizer's cultural habits, assumptions, institutions and values, the result is never a simple reproduction of those traits. Rather, the result is a 'blurred copy' of the colonizer that can be quite threatening. This is because mimicry is never far from mockery, since it can appear to parody whatever it mimics. Mimicry therefore locates a crack in the certainty of colonial dominance, an uncertainty in its control of the behavior of the colonized. (139) 
Here, we can easily affix Macaulay's golden words too to his character as he becomes an "... Indian in blood and colour, but English in tastes, in opinions, in morals and in intellect" (Macaulay 1835). This is how Kip's own identity is diluted and he is slowly converted to a state of hybridity, causing major changes in his real, previous being. Here, language naturally becomes the first medium of mimicry getting him Anglicized, but as Benedict Anderson says "to be Anglicized is emphatically not to be English" (qtd. in Bhabha 87). Such an issue of identitycastration is not only found in Ondaatje's The English Patient but also seen in V. S. Naipaul's well-recognized novel The Mimic Man (1967) where Kripal Singh is converted to Ralph Singh as per the need of the West.

Kip initially appears to be an inexperienced fellow, has been slowly moulded and used perfectly by Lord Suffolk. Suffolk appears to be a kind hearted man with little regard for racial superiority unlike other Englishmen. But, his commanding role, his efficiency in controlling twelve workers from different parts of the world at a time speaks for his authoritative attitude and supremacy like a colonizer. Though Suffolk has welcomed Kip to his English bomb defusing team in a gentle manner, his way of administering Kip during the training stipulates his colonial attitude which no reader can connive at. Suffolk has talked a lot about England's culture, customs, and its people to Kip "as it [is] a recently discovered" (Ondaatje 197). Kip initially struggles to adjust himself to new environment of the West, but he, under the coverage and care of Suffolk, slowly gets attracted to the English food, songs, festivals and movies which nourish him with their warmth. The English culture, in the words of Ngũgĩ Wa Thiong'o, is like a 'cultural bomb' that explicitly wipes out his aboriginal histories. "The effect of the cultural bomb is to annihilate a people's belief in their names, in their languages, in their environments, in their heritage of struggle, in their unity, in their capacities and ultimately in themselves" (Thiong'o 3). Kip believes in strong characteristics of the opponents, takes his enemy seriously but he has failed to completely fathom the reasons and motives behind the kindness of Suffolk. Kip also starts forgetting his own family members, culture, and 'homeland' in touch of the West. Frantz Fanon in his The Wretched of the Earth says, "For a colonized people the most essential value, because the most concrete, is first and foremost the land: the land which will bring them bread and, above all, dignity" (Fanon 43). We can recapitulate his transformation by Fanon's other words,

Having judged, condemned, abandoned his cultural forms, his language, his food habits, his sexual behavior, his way of sitting down, of resting, of laughing, of enjoying himself, the oppressed flings himself upon the imposed culture with the desperation of a drowning man. (Fanon 39)

England is not Kip's own native soil but he loves to be there and loves to work under Lord Suffolk. Suffolk gathers a number of talented sappers like Kip from 
all over the world during the Second World War. Suffolk takes good care of Kip when he joins as a lonely foreigner, coming from an English colony, in England. He welcomes him open heartedly in his bomb defusing team like a family member. "After a year abroad, as if he were the prodigal returned, [offers] a chair at the table, [embraces] with conversations" (Ondaatje 202). Suffolk's father-like attitude towards Kip is very significant from colonial point of view. Kip's proper transformation begins when he starts participating in bomb diffusion actively under his guidance. Kip makes efforts to mould himself as per the expectations of his foreign colleagues where he is a single minority; pleasing them with good work and a bearable behavior becomes a mantra of his life and living. "Although he [is] a man from Asia who [has] in these last years of war [assumes] English fathers, following their codes like a dutiful son" (Ondaatje 229). The British army teaches him the skills how to defuse bombs and then the Americans teach him the further skills. Kip might not have taken it as suffering but his situation, in spite of his impressive demeanour, makes him look vulnerable amidst bombs and Whites. Kip's ability to obey and endure the colonizer makes him an adorable disciple, making him an exemplary colonized being for colonization does begin with the promise of better education and enlightenment.

Kip further wishes to accomplish some of the power of colonizers and his dreams gets fulfilled only after Suffolk's death. He, after Suffolk's death, becomes the master and trainer of the British sappers. Here, the whole scenario is changed as the colonizers (the British sappers) become the students of the colonized (Kip); a reversal of typical race role. Hardy easily accepts Kip as his boss and barks out the word 'sir' loud and enthusiastically so many times. "Though Kip [is] ten years younger than Hardy and [is] not an Englishman but he [is] happiest in the cocoon of regimental discipline" (Ondaatje 225). Here, we find the juxtaposition of mimicry and reverse mimicry; the colonized (Kip) mimics the colonizers (represented by Suffolk) and the colonizers (represented by Hardy) mimic the colonized (Kip). Interestingly, this reminds one of Kim, a creation of Kipling who fondly terms himself as a 'Chela' — an Indian word for a 'disciple' with a tongue in cheek satirical ring. Chela is usually understood to be a mindless follower of the guru/guide who himself/herself can also acquire the position of a guide in the long run.

Kip is accepted and regarded optimistically by others like Hana, a nurse from Canada and Caravaggio, an Italian thief. Hana, like Kip, breaks the ethno-racial boundaries traveling all through the Golden Temple with the wings of her imagination. Through an aesthetic description of the Golden Temple of India, Ondaatje tries to omit at least the religious and nationalistic gulf between an 'Asian Other' (Kip) and a 'Western observer' (Hana). The relationship breaks the demarcation and voices for a melting pot where a colonizer like Hana can easily 
engulf with the colonized, Kip. He, as a sapper, saves countless lives valuing human lives over nationalism and debunking ethnocentric views. The most surprising yet very natural conclusion is the formation of a community without nationalities and borders among them, however fragile in its nature as they live together. The magic of this book can be ascribed to a great extent, to this aspect of their life; four persons (Almasy, Kip, Hana, and Caravaggio) from different countries, which are almost at war with each other, tearing one another, have agreed to live together under the same roof of an Italian villa. They care for each other; their suspicions about each other have washed out, Kip and Hana romance around. Positively, Ondaatje, through the portrayal of Kip, wants to create "a new system of mobile relationships [which] must replace the hierarchies inherited from [colonialism and] imperialism" (Said 274). Ondaatje through his transformation and unification with others creates a theory of 'oneness', instead of 'ownership'. It signifies the de-centrality of any dissection of humans on the basis of racial and ethnic norms. They have formed a world of their own in its pure, primeval form.

Kip works with faith, honesty, and brotherhood with other sappers, but fails to get the same treatment reciprocally from the Englishmen, except some conditional care and love from Suffolk and Hardy. Here, Ondaatje has shown the hollowness of English people as they, decidedly professional, only expect people to work and yield according to their order and will. Moreover, despite such cultural transition and affection to the Western people, Kip has failed to change his earlier eating-habit and behaviour highlighting his affiliation to India and Indian culture. The repeated references and allusions to Kip's 'brown hand' and 'brown wrist' persistently remind him of his aborigine identity, depicting his ambivalent nature, "a signifier without signified" (Hilger 42). Due to such effect, Kip, in the words of a poststructuralist theorist Jacques Derrida, can be defined as an "indefinite referral of signifier to signified" (qtd. in Chandler 79). In the word of Derrida, it refers to the 'play' or 'freeplay' of such signifier. Kip, according to the French psychoanalyst Jacques Lacan, remains "the incessant sliding of the signified under the signifier" (qtd. in Chandler 79). Such decentral identity is much comparable to Stuart Hall's elaboration of 'race' as a floating signifier. Kip's fluid identity has helped him to realize the cold commanding attitude of dominant English people in the second half of the story when the two destructive atom bombs drop on Hiroshima and Nagasaki by Americans wake him up abruptly from the trance he is living through. It is a trance caused by his blind faith in his masters and the instilled conviction that the Whites are the saviours of the East. He finds the mask removed suddenly, from their faces. They are barbarians of another level. He feels many things changing across the previously enjoyed harmony of his colleagues and seniors. "So quickly [has] London gone sour on [him]. The great city, center of the world, in which, fleeing disorder, [falsely he has] hoped to find the beginning of order" (Ondaatje 18). Kip who has earlier rejected his family, culture 
and activity in order to adopt the culture and food habit of the Western people, decides to return back to India. He says, “American, French, I don't care. When you [start] bombing the brown races of the world, you're an Englishman. You had king Leopold of Belgium and now you have fucking Harry Truman [then the president] of the USA. You all learned it from the English" (Ondaatje 304). As far as such barbaric attack is concerned, the 'brown' race "... would have never dropped such a bomb on white nation" (Ondaatje 304).

\section{Kim and Reverse Mimicry}

Rudyard Kipling, an Indian-born English author and critic, has openly glorified British imperialism in his famous poems "Ave Imperatrix" and "The White Man's Burden". For the reason, he is considered to be the "Poet of the Empire" (Besant 1900) and "the prophet of British imperialism" (Orwell 1942) but we cannot deflate the "existence of an anti-imperial presence" (Wegner 140) from the narration of his writings like Kim, a spy thriller and coming-of-age novel, published in the year of 1901. The novel Kim, which is written in the milieu of the collapse of the British imperial power in South-East Asia, is “... a positive, detailed, and non-stereotypical portrait of the colonized that is unique in colonialist literature" (Jan Mohamad 97).

Kim is a son of an Irish soldier, grown up in the streets of Lahore city which is situated in the Punjab province, which was once the capital of the Sultanate Dynasty of India. Kim spends the early important years of his childhood there. He comes from a well-off family background and golden times: his mother Annie Shott was a nursemaid in the family of a Colonel and his father Kimball O'Hara was a sergeant of the Mavericks of an Irish regiment in Punjab and Delhi Railway. Later, they were brought down to a poverty-stricken life after the fall of Irish regiment in South-East Asia. After departure of the Irish, O'Hara and his family stayed back in India but they started losing their grandeur in the hands of time as his

...wife died of cholera in Ferozepore, and after that, O'Hara fell to drink and loafing up and down the line with the keen-eyed three-year-old baby. Societies and chaplains, anxious for the child, tried to catch him, but O'Hara drifted away, till he came across the woman who took opium and learned the taste from her, and died as poor whites die in India. (Kipling, Kim 2)

Kim starts growing up with an unremitting influence of the Eastern people and their culture. Kim “... has lost his own country and has not acquired any other. But he has a most complete hatred of his conquerors" (Kipling, Kim 277). "Kim delights in changing his appearance and identity in becoming Other, and he loves 
to live in a world of pure becoming. His is a world of infinitive concrete potentiality ... Endowed by the narrator with special talents, he can do anything and become anybody" (qtd. in Wegner 148). He is fated for the life of an interracial mixing, cancelling out Kipling's imperial motive: "a man should, whatever happens, keep to his own caste, race, and breed. Let the white go to the white and the black to the black" (Kipling, Plain Tales 147). Kip, a baptized Christian, disguises himself as a Muslim and is fascinated by the sacrosanct Haj dinner. Besides these, "Kim [learns] whole chapters of the Koran by heart, till he [can] deliver them with the very roll and cadence of a mullah" (Kipling, Kim 195-96). Religion has no primacy in his life,

$\ldots$ in the land of many religions, he changes from a Hindu to a Muslim, from a Muslim to a Buddhist, from a Buddhist to a Christian, and then begins the cycle (of disguise) all over again. Along the way he adopts innumerable minor identities and disguises, further proliferating the play of subjectivities. (Wegner 148)

For the reason, we can find fluidity in Kim's subjectivity like Ondaatje's Kip. From Kim's appearance Arthur Bennett, a British minster, mistakenly judges him as a local thief but later Bennett recognizes his real identity. Bennett tells him to move to Masonic Orphanage but for Kim it would mean looking back. He wants to move ahead and explore everything in and about India.

Kipling's Kim is about Kim's journey from Lahore to different parts of India with his master Lama who has guided and shown him the right path. He has gone through a long winding process of changes - "he transforms himself from a common street urchin to the Lama's dedicated chela to a star student at St. Xavier's to a significant new player in the Game" (Wegner 148). He feels tired of Lahore city so he wishes to experience air and water of India, mainly in the cities of Benaras and Lucknow. Kip's journey from Lahore is nothing but a quest for new identity which he searches for in company of the Lama in the land of India. Peace is their grail. Kim, 'Little Friend of all the World' has gone through it all, has begging, doing all kind of errands in the street of Lahore before entering to his another vagrant life in the 19th Century British India. Kim also helps lama to get food in Lahore from a woman, and their sharing of food reveals the East-West unison. Lama, a colonized, is from Tibet while Kim is a figure standing for a colonizer, is from Irish family but both approach life united by a semblance of thought despite their cultural diversity. They never let the gulf of difference evolve between them, taking each other as fellow beings paves the way for a new company and community rather. Lama is a man under whose guidance Kim matures, he is the guardian angel: "He is not a fakir. He is not a down-country beggar. He is the most holy of holy men. He is above all castes; I am his chela" (Kipling, Kim 78). He does not feel discomfiture to call himself a chela of Lama 
that "I am now that holy man's disciple" (Kipling, Kim 22). He never wants to leave him; no one can take him away from him. Bennett wants to take Kim away from India but Kim is not in a mood to return back rather he ensures lama (his master) that he will rejoin him to find the River of the Arrow, as he rejoins him later. Kim becomes a dependent on the Lama for all his whims and decisions, and considers him as his father and mother as he once bursts into a flood of tears. He has loving affections for lama and later reveals that they are rather interdependent. As Kipling makes Kim think aloud, he is “...the prop of lama's declining years, and that the lama would die without his care" (Kipling, Kim 34). The Lama can be taken as the archetype of the wise old man, who instructs, guides and even assaults a fledgling hero with a purpose of helping him in his adventures of life.

Kim has worked as a messenger, a spy under Mahbub Ali, and a horse trader, who knows how to execute all secret business by keeping master's faith. Kim is "... the one soul in the world who [has] never told him a lie" (Kipling, Kim 26). On one occasion, Kip has to hide himself in a nearby hedge in order to deliver a message given by Mahbub Ali at an Englishman's place. Kim, without disclosing his identity, throws it to his feet and he is paid back for troubles by the Englishman by dropping a coin on the ground. The dropping of a coin, instead of paying at his hand, shows the disrespect and indifferent attitude like a typical colonizer to a colonized. Thus, Kim, though has a blood of West, is treated like a person of the East.

Kim also bears unique views regarding India: he not only defines India as an only democratic land in the world but also prefers to speak in vernacular Indian languages though he is an Irish. Despite being a man of White class, he is able to speak a comprehensible Urdu language. He has adopted that very 'clumsy Urdu' and Hindi, words like 'Maharaj' (emperor), 'pahari' (Hillman), 'shabash' (bravo!), and 'Pardesi' (a foreigner) etc., make part of his lingo. He is mocked by a drummer-boy for talking in an Indian language. The boy believes that the Indian language does not suit the White people like Kim but he doesn't feel offended for such opinions. The drummer-boy further talks about England, basically Liverpool suburb but Kim does not show any concern for it. He remains very casual about his native culture and its people. He seems to have rejected it long ago. He has nothing to do with "his [lost] country - his race-his village" (Kipling, Kim 22). Lurgan, like Kim, is also influenced by the Eastern culture and its people revealed through his vast knowledge on the South Asian culture. Moreover, he has multiple sides to his identity; he can also fluently speak Urdu language does not seem English at all. It would not be an exaggeration to say that he has lost his attachment to the West in touch of the East. Kipling, through such narration, demands to bridge the gap between the ruler and ruled. 
A half-caste opium addicted woman who looks after Kim is his mother's sister, as claimed by the woman herself. She, with tears, insists him to wear the European clothes: a shirt, trousers, and a battered hat but Kim doesn't care for it. He feels comfortable with the usual Desi (native) garb: he finds "it easier to slip into Hindu or Muhammadan garb" (Kipling, Kim 4). Accordingly, Kim wholeheartedly accepts a complete suite of Hindu kit given by a fashionable man. It is

[the] costume of a low-caste street boy, and Kim [stores] it in a secret place under some baulks in Nil Ram's timber yard, beyond the Punjab High Court, where the fragrant deodar logs lie seasoning after they have driven down the Ravi.... Sometimes there [is] food in the house, more often there [is] not, and then Kim [goes] out again to eat with his native friend. (Kipling, Kim 4)

Kim also loves to eat food with poor people of the Asia. There are ash-smeared fakirs (holy men) "with whom he [is] quite familiar - getting them as they [return] from begging tours, and, when non one [is] by, eating from the same dish" (Kipling, Kim 3). Kim has truly loved them and unconditionally accepted their dress and food. Such assertive behaviour at the Eastern people deconstructs the man-made racial dichotomy between the East and the West. Thus, with mimicry as the medium of survival is causing Kim's identity to traverse through myriad changes; seasons, places and people affect his persona all the times.

Kim, due to the influence of Indo-English culture, has kept himself in a state of ambivalence. Besides it, Kim, more or less, shows his neutral attitude towards the East and its people unlike typical colonizers. In the beginning of the novel, he consorts " ... on terms of perfect equality with the small boys of the bazaar; Kim [is] white - a poor white of the very poorest" (Kipling, Kim 1). In spite of being a man of upper class family in blood, he boards a jam-packed train fully incarcerated with diverse group of people like a Hindu Jat farmer, Hindu banker, Sikh craftsman, and Dogra soldier etc. He does not hesitate to sit “... side by side with all castes and peoples" (Kipling, Kim 32). In the train, "All castes and kind of men move here. Look! Brahmins and chamars, bankers and tinkers, barbers and baniyas, pilgrims and potters - all the world going and coming. It is to me as a river from which I am withdrawn like a log after a flood" (Kipling, Kim 65). The train becomes a place where opposite of everything is being debunked; everyone becomes equal, as stated by Mikhail Bakhtin in his theory of 'carnivalism'. Kip's exceptional approach and behaviour towards Indians in spite of being a man of White race demystify the stereotypical concept of nationalism. Creighton Sahib encourages and advises Kim not to change his attitude and sympathy for the local cultures and its people. Though Kim's adaptation of the Eastern culture has made him Indian, he cannot hide his European identity as meticulously revealed by 
Father Victor in the novel. "Father Victor [steps] forward quickly and [opens] the front of Kim's upper garment" (Kipling, Kim 99) and speaks to Bennet,

'You see, Bennett, he's not very black. What's your name?'

'Kim.'

'Or Kimball?'

'Perhaps. Will you let me go away?'

'What else?'

'They call me Kim Rishtike. That is Kim of the Rishte.'

'What is that - 'Rishte'?'

'Eye-rishti — that was the Regiment - my father's.'

'Irish—oh, I see.'

'Yes. That was how my father told me. My father, he has lived.'

'Has lived where?'

'Has lived. Of course he is dead-gone-out.'

'Oh! That's your abrupt way of putting it, is it?'

'He is certainly white, though evidently neglected.' (Kipling, Kim 99)

\section{Conclusion}

Mimicry can thus, be read in multiple ways. While Bakha in M. R. Anand's Untouchable mimics a soldier to look different and acquire a momentary sense of independence from shackles of caste inferiority, Najeeb in Kamila Shamsie's God in Every Stone mimics English men sartorially to make his friend and guide, Vivien Rose, happy and accepted in Lahore. Kim and Kip are examples of going through a long drawn process of growing up, looking into the mirror of mimicry. Kim, by the virtue of living in close company of Indians, adopts their habits and manners without any qualm, in a most unconscious manner. He never bothered to look or sound his original self which he had not experienced for long. Thus, a kind of reverse mimicry is his fate and character when we look at him as an outsider living as an Indian native. Luckily he has an easy sail, he is accepted by all and treated affectionately by most. The doubt and rejection by a few to take Kim as one's own is another aspect of this mimicry. It is something that our diaspora experiences even in present day democracies, Gogol in Lahiri's novel The Namesake finally does decide to repatriate to India even though he was born and brought up in New York. Kip joins the English army as a grown up, learns the need to show affinity to the new culture by way of imitation and mimicry, adopting their ways to weave a comfort zone. Being different could be an assaulting fact 
for both sides, he was quick to realize that. But his childish view of looking down upon his native culture is the irony of mimicry. It wipes out the original self to rewrite a new identity. Kip leaves that small community sprouted accidentally in the Italian monastery, showing traces of a stricken conscience. The ambivalence of their character is an interesting aspect of mimicry presented by Kim and Kip.

\section{WORKS CITED}

Anand, Mulk Raj. Untouchable. New Delhi: Mayfair Paperbacks, 1981.

Ashcroft, Bill, et al. Post-Colonial Studies: Key Concepts in Post-Colonial Studies. New York: Routledge, 1998. 139.

Besant, Walter. "Is It the Voice of the Hooligan?" The Living Age. 17 February 1900.

Bhabha, Homi K. The Location of Culture. New York: Routledge, 1994. 86-88.

Chandler, Daniel. Semiotics: The Basics. New York: Routledge, 2007. DOI: https://doi.org/10.4324/9780203014936

Derrida, Jacques. Writing and Difference. Trans. Alan Bass. London: Routledge, 1978.

Fanon, Frantz. The Wretched of the Earth. Trans. Constance Farrington. New York: Grove Weidenfeld, 1963. 39-43.

Hilger, Stephanie M. "Ondaatje's The English Patient and Rewriting History". Comparative Cultural Studies and Michael Ondaatje's Writings. Ed. Steven Totosy de Zepetnek. Indiana: Purdue University Press, 2005. 3848. DOI: https://doi.org/10.2307/j.ctt6wq1zh.7

Hornby, A. S. Oxford Advanced Learner's Dictionary. Eds. Joane Turnball et al. Oxford: Oxford University Press, 2010. 852.

Jan Mohammed, Abdul R. "The Economy of Manichean Allegory: The Function of Racial Difference in Colonialist Literature". Race, Writing, and Difference. Ed. Henry Louis Gates. Jr. Chicago: University of Chicago Press, 1986. 78-106.

Kipling, Rudyard. Kim. New Delhi: Rupa Publications India, 2012.

---. "Beyond the Pale". Plain Tales from the Hills. Calcutta: Thacker Spink and Co., 1888. 
Lacan, Jacques. "The Line and Light". The Four Fundamental Concepts of Psycho-Analysis. Trans. Alan Sheridan. New York: Norton, 1978.

Lahiri, Jhumpa. The Namesake. Boston: Houghton Mifflin Harcourt, 2003.

Loomba, Ania. Colonialism/Postcolonialsim: The New Critical Idiom. 1998. 2nd ed. Abington, Oxon; New York: Routledge, 2005.

Macaulay, T. B. "Minute by the Hon'ble T. B. Macaulay, dated the 2nd February 1835". From Bureau of Education. Selections from Educational Records, Part I (1781-1839). Ed. H. Sharp. Calcutta: Superintendent, Government Printing, 1920. Reprint. Delhi: National Archives of India, 1965. 107117. Web. $16 \quad$ Nov. 2018. <http://www.columbia.edu/itc/mealac/pritchett/00generallinks/macaula y/txt_minute_education_1835.html>.

Myers, Mitzi. “Of Mimicry and (Wo)Man: Infans or Forked Tongue?" Children's Literature 23 (1995): 66-70. DOI: https://doi.org/10.1353/chl.0.0288

Ondaatje, Michael. The English Patient. London: Bloomsbury Publication, 2004.

Orwell, George. "Rudyard Kipling." Horizon. GB, London. February 1942. Web. 13 Feb. 2018. <https://orwell.ru/library/reviews/kipling/english/e_rkip>.

Robinson, Mairi and George W. Davidson. Chambers 21st Century Dictionary. New Delhi: Allied Publishers Private Limited, 2001.

Said, Edward W. Orientalism: Western Conceptions of the Orient. New York: Vintage Books, 1979.

Shamsie, Kamila. God in Every Stone. New Delhi: Bloomsbury, 2014.

Singh, Amardeep. "Mimicry and Hybridity in Plain English" (08 May 2009). Web. 12 Jan. 2017. <https://www.lehigh.edu/ amsp/2009/05/mimicryand-hybridity-in-plain-english.html >

Thiong'o, Ngũgĩwa. Decolonizing the Mind: The Politics of Language in African Literature. Zimbabwe: Zimbabwe Publishing House, 1994.

Wegner, E. Philip. "Life as He Would Have It: The Invention of India in Kipling's Kim". Cultural Critique 26 (Winter 1993-94): 140-48. DOI: https://doi.org/10.2307/1354458

Received March 19, 2019

Revised version accepted November 15, 2020 